بررسى روند تغييرات كاربرى اراضى در بالادست حوضه سد زايندهرود مطالعه موردى: (حوضه آبخيز توف سفيد، استان جهارمحال و بختيارى)

مهدى يُوهش”، لطفعلى جر اغيور، عليرضا داووديان و عاطفه بزر كمهر'

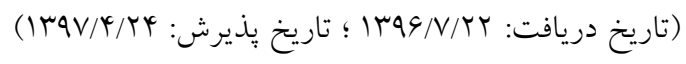

جكيده

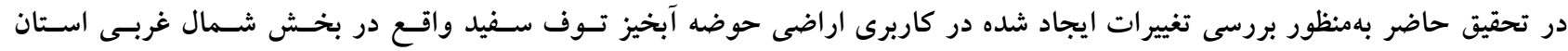

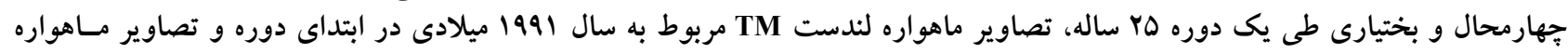

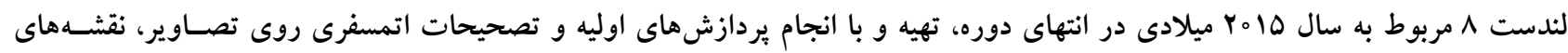

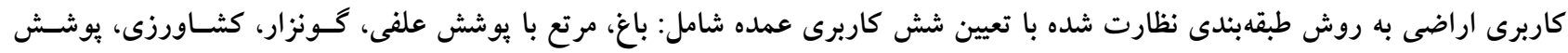

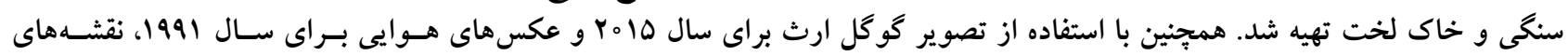

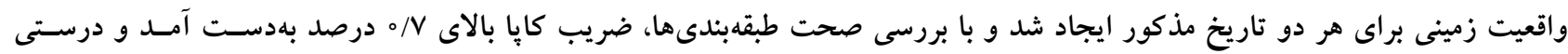

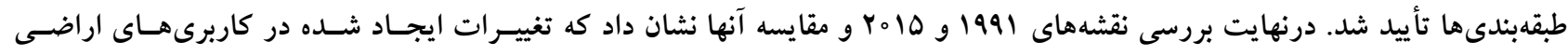

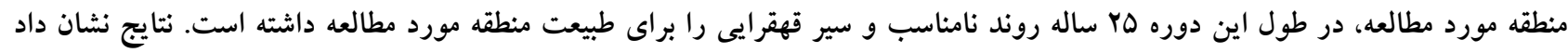

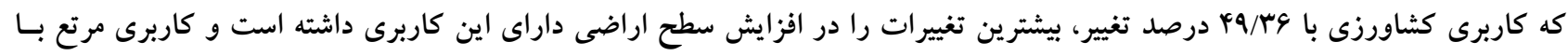

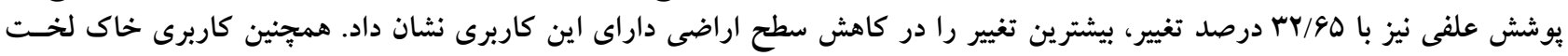

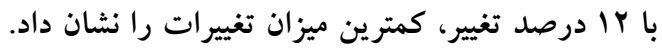

وازههاى كليدى: تصاوير ماهوارهاى، تغييرات كاربرى اراضى، طبقبندى نظارت شده، ضريب كإِا.

1. كروه مرتع و آبخيزدارى، دانشكده منابع طبيعى و علوم زمين، دانشكاه شهركرد، شهركرد

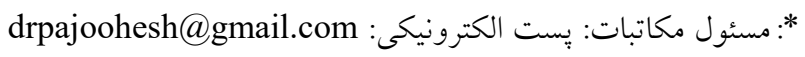


اصلى كاهش توليدات كشاورزى در واحد سطح و نيز تغييـرات

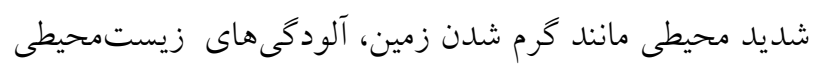

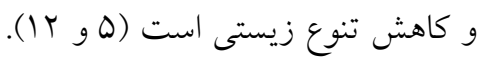

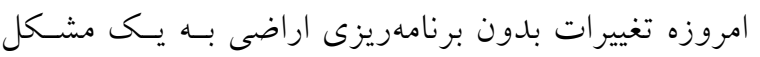

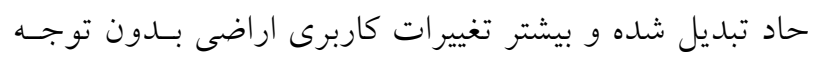

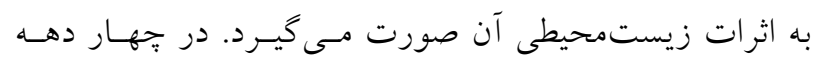

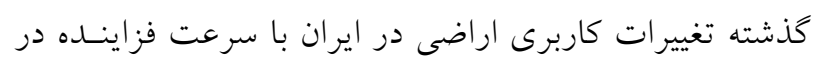
بعضى جهات نامطلوب به وقوع ييوسته و اين باعـث تشـديد روند تخريب اراضى شده اسـت. امــروزه استفاده از فنـاورى سنجش از دور بـهـعنوان يكسى از منــابع مهـم بــراى مـديريت

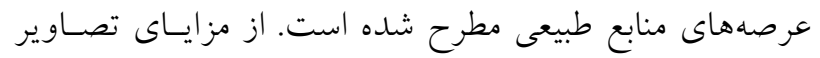
ماهوارهاى مىتوان دسترسى به نقاط دور افتـاده و كوهستسانى،

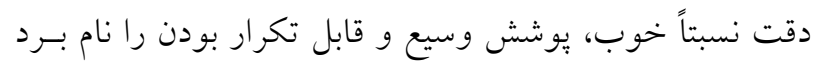

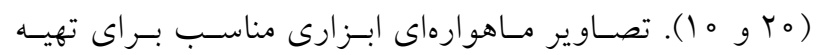
نقشههاى كاربرى اراضس و سـسـ ارزيسابى تغييـرات محسيط

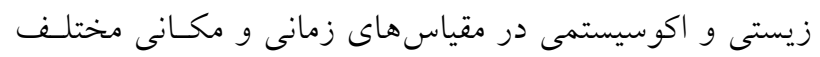

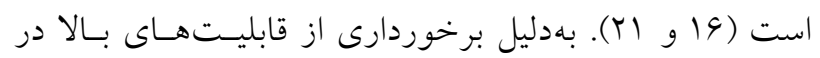

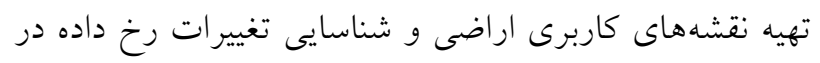

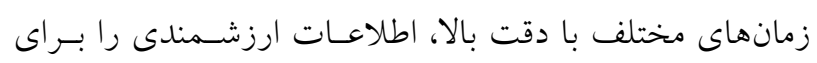

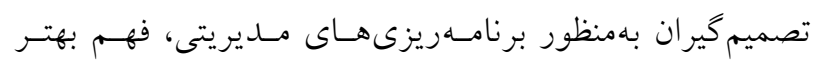

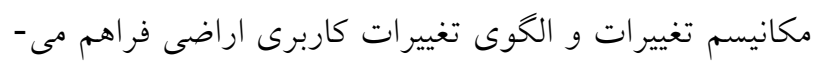

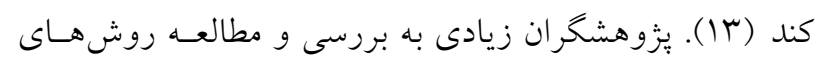

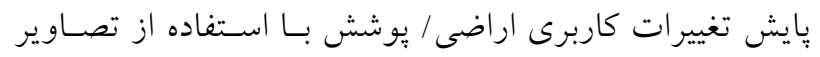

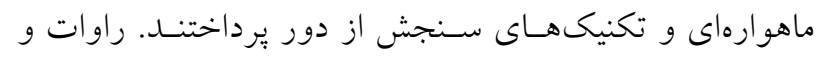

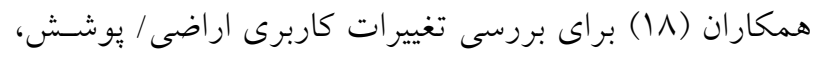

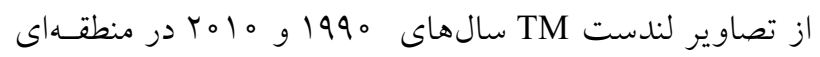

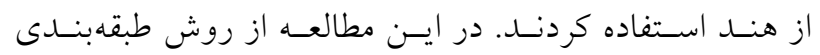

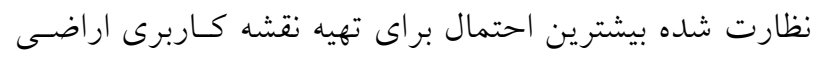

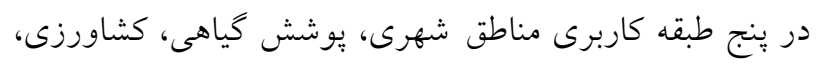

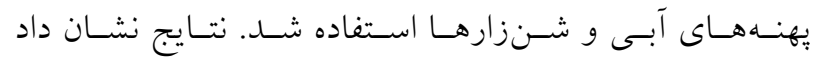

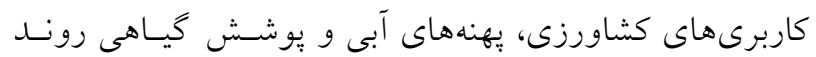
كاهشى داشته و شنزارها و مناطق مسكونى در دوره مب ساله

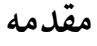

استفاده از زمين بدون در نظر گرفتن توانهاى محيطى آن، باعث

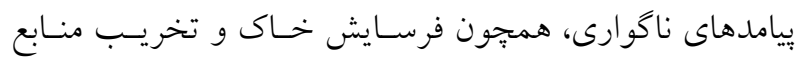

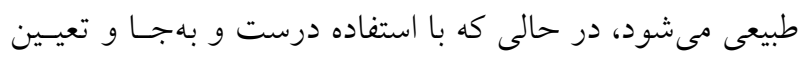

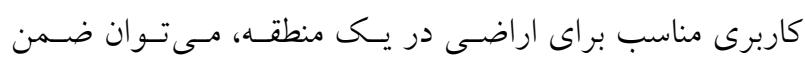

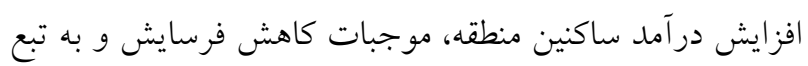

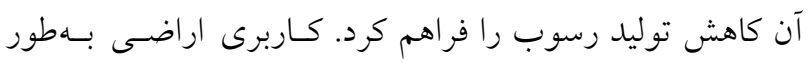
ذاتى درباره همه جنبههاى فضايى و فعاليتهاى انسان در زمسين و طريقهاى كه سطح زمين مى تواند براى نيازهاى مختلف دهائ آمـاده

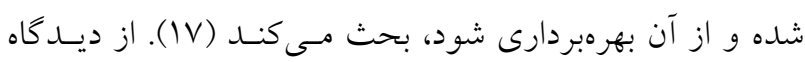

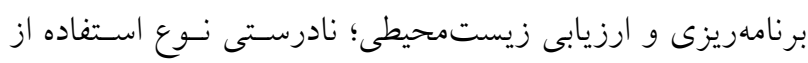

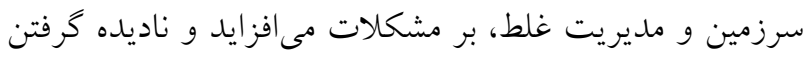

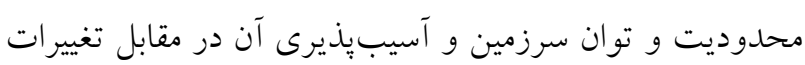

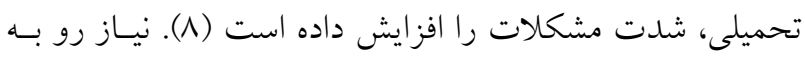

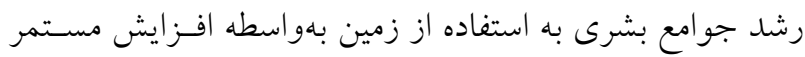

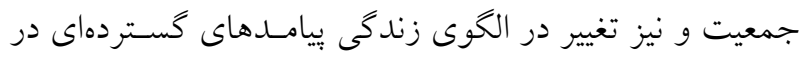
سرتاسر كره زمين داشته است. تغيير كاربرىهاى مختلف زمسين

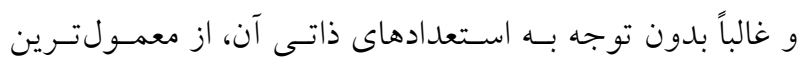

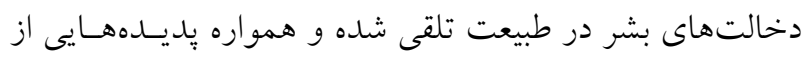

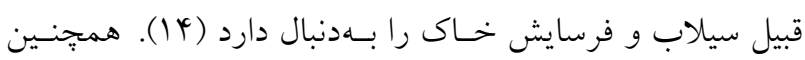

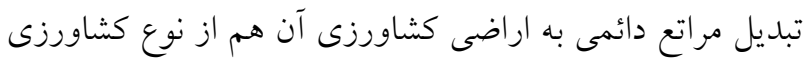

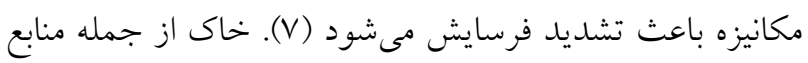

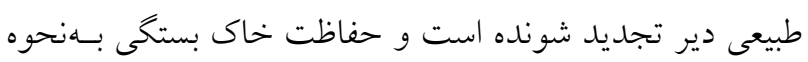

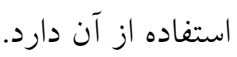

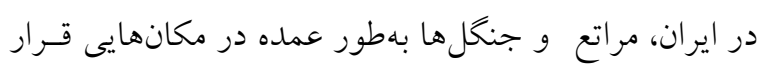

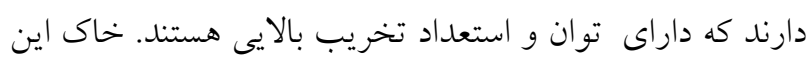

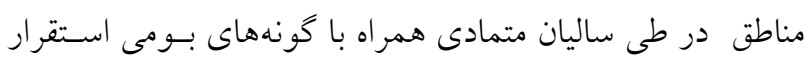

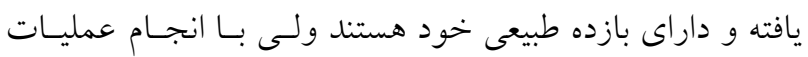

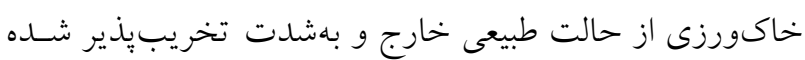

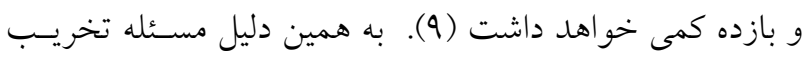

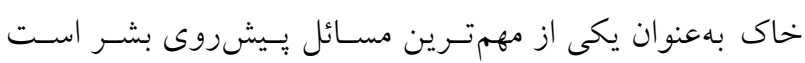

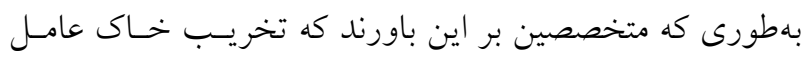


سد زايندهرود و تأمين كننده آب مناطق باييندست سد اسـت، از

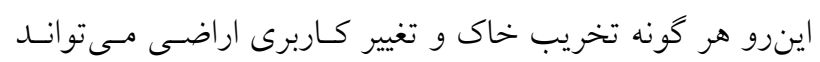

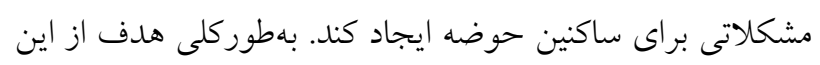

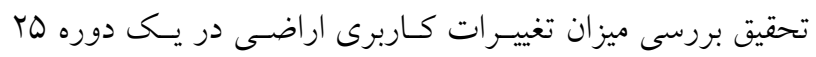

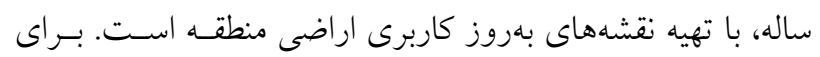
اين منظور روند تغييرات كاربرىها در طى زمان مشخص مى شیود

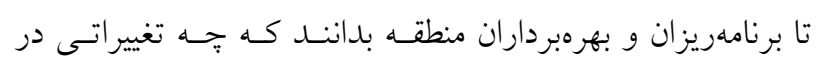

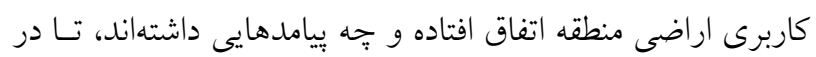
آينده با برنامهريزى بهترى از اراضى منطقه استفاده كنند.

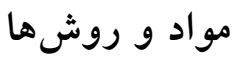 منطقه مورد مطالعه}

منطقه مورد مطالعه حوضه توف سفيد، قسمتى از حوضه آبخيـز

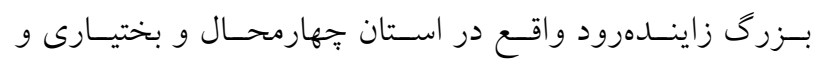

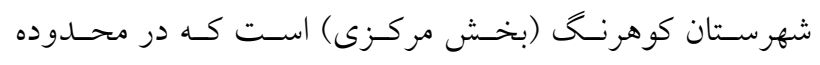

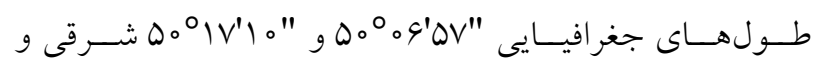

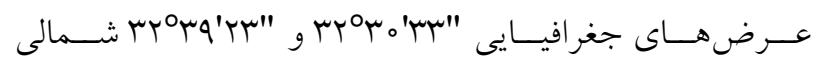

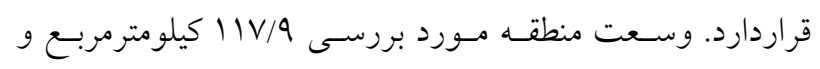

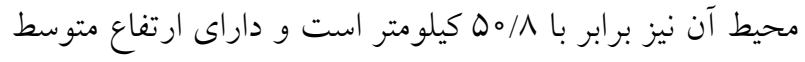

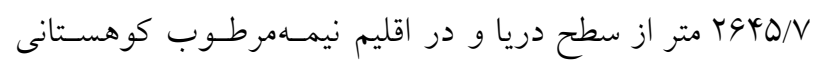

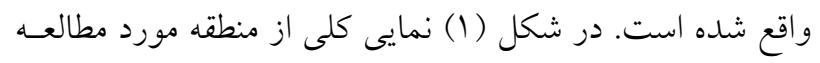

نشان داده شده است.

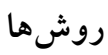

براى بررسى تغييرات ايجاد شده در كاربرىهاى اراضى منطقـه،

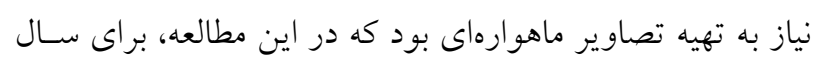

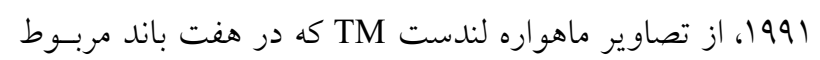

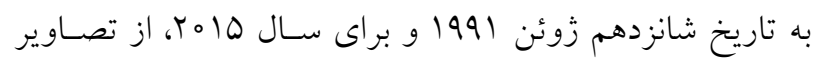

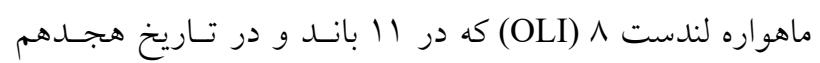

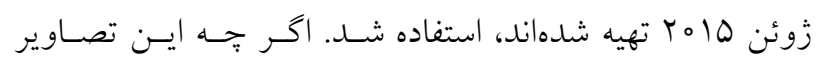

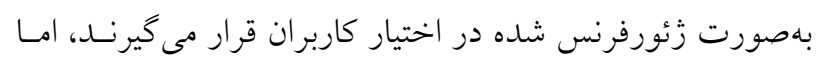
براى حصول اطمينان از موقعيت مكانى عوارض، عمليات زمين
توسعه بيدا كرده است. عبـدلكاوى و همكـاران (1) بهوسـيله

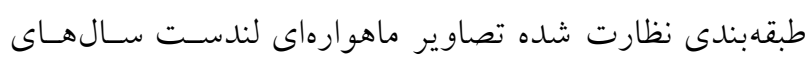

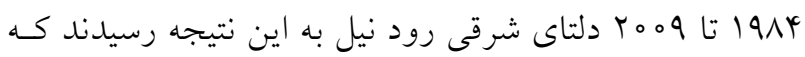

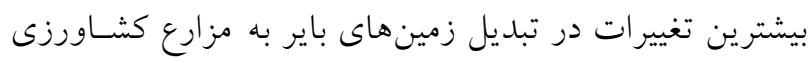

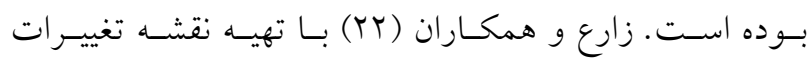

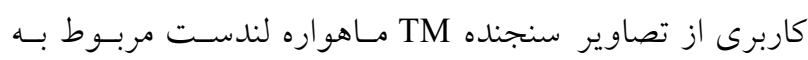

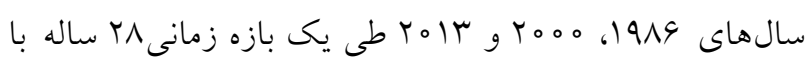

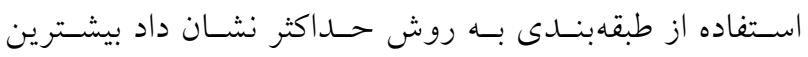

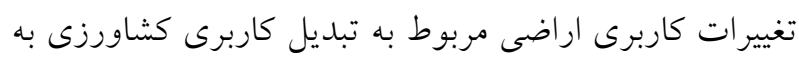
كاربرى شهرى در منطقه نور بوده، بهطورى كه روند تغييـرات

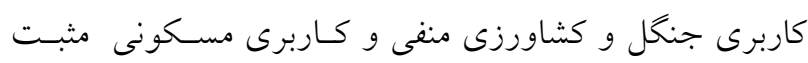

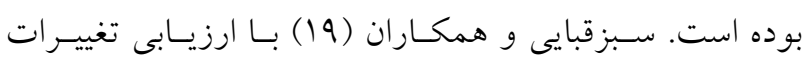

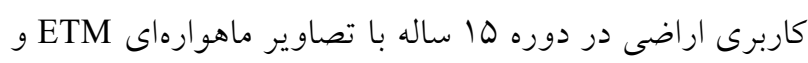
OLI

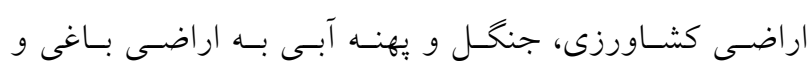

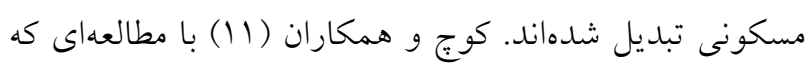

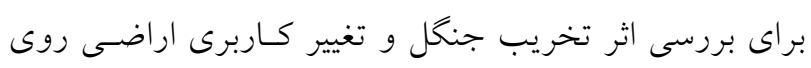

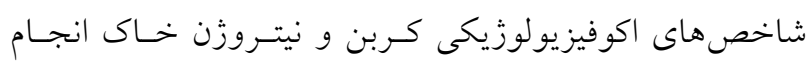

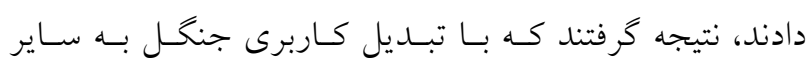
كاربرىها كيفيت زيستى خاى كاهش معنى دارى يافتـه اسـت.

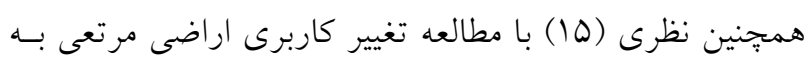

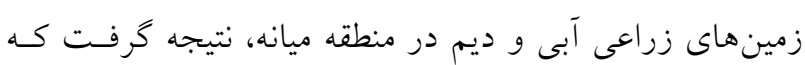

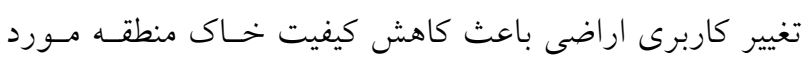

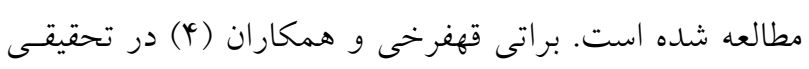

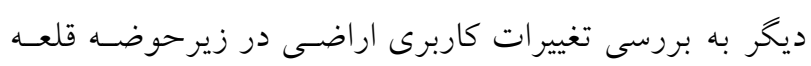

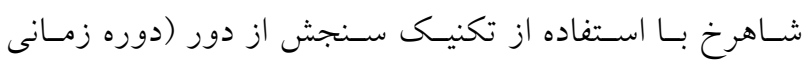

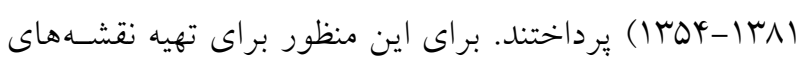

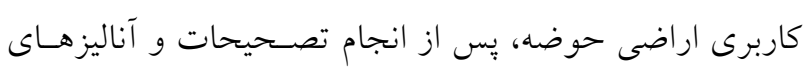

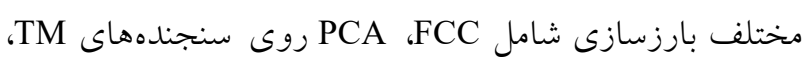

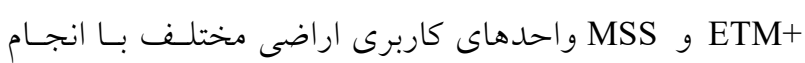
نمونهبردارى تصادفى طبقهبندى و بررسى شد.

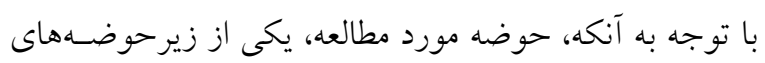




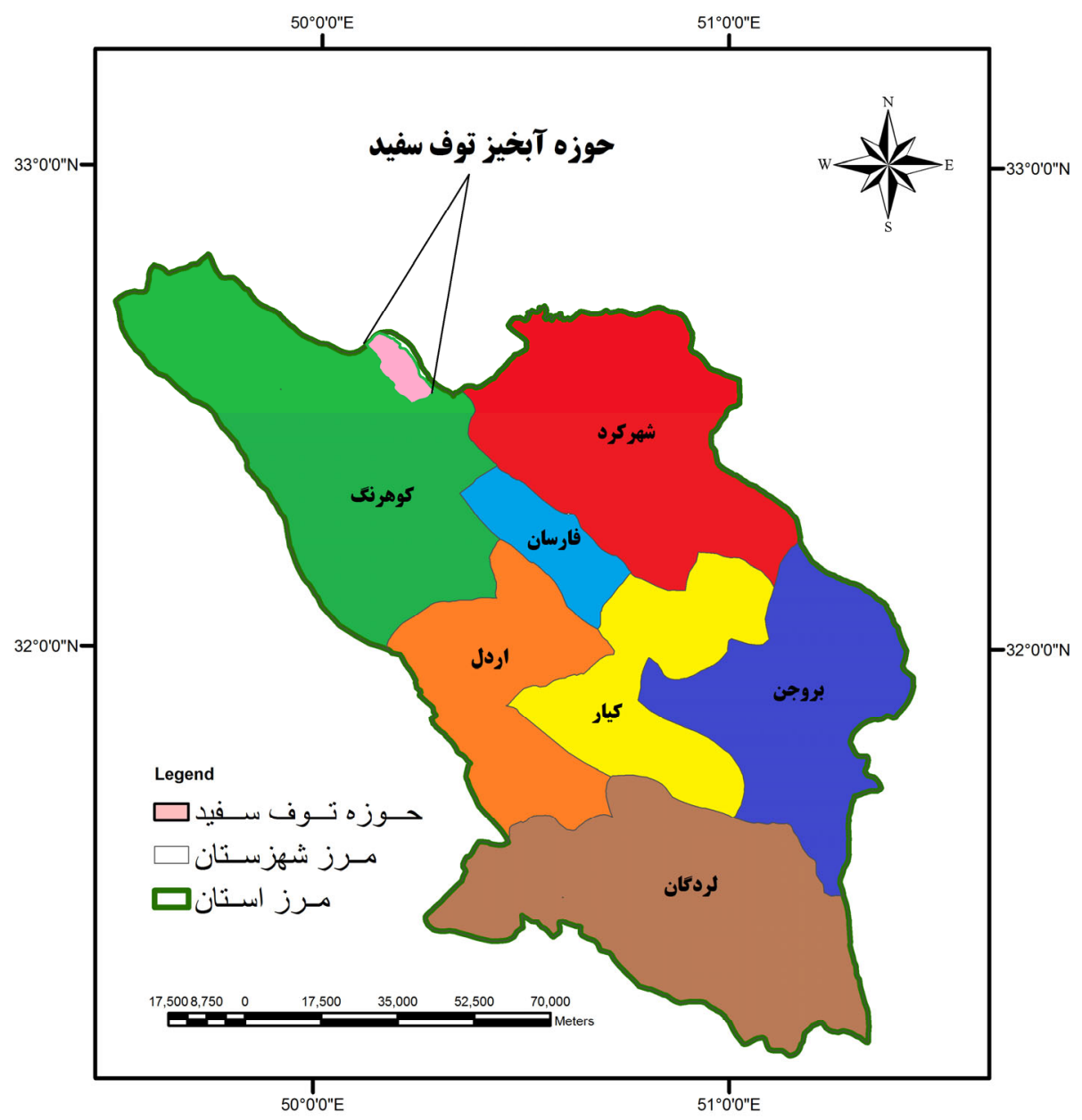

شكل 1. موقعيت حوضه آبخيز مورد مطالعه (حوضه توف سفيد) در استان جهارمحال و بختيارى

ايجاد تصوير تركيب رنكى كاذب، عوارض با وضوح بيشـتر در تفكيك كاربرىها و بررسى بوشش هاى گياهى با دقت بيشـترى استفاده شد. با توجه به بازديدهاى ميدانى و برداشتن نقاط شاهد زمينسى از كاربرىهاى مختلف منطقه با استفاده از GPS، شش كـاربرى

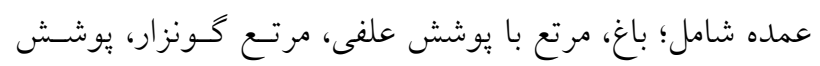

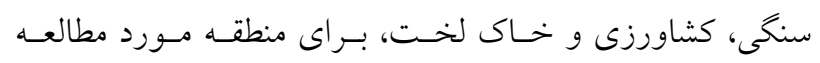

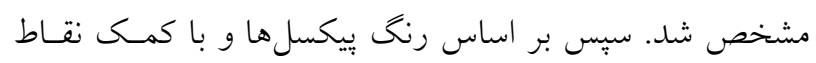
شاهد زمينى، از روى تصاوير تركيب رنخى تهيه شده، نمونههاى

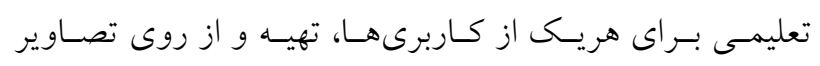
رقومىسازى شده بهصورت يك فايل وكتورى ذخيره شدند. در ادامه طبقهبندى نظارت شده به روش حداكثر احتمال، انجـام، و نقشههاى كاربرى اراضى تهيه شد. بهمنظور ارزيابى دقت يّايخـاه
مرجعسازى، مجدداً انجام شد. اندازه بيكسل ها در ايسن تصـاوير هم در هم متر اسـت. بـردازشهـاى اوليسه شـامل؛ تصسحيحات

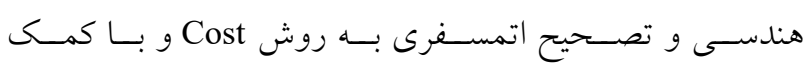
جار امترهاى سال، ماه، روز تصـويربردارى، زاويـهـ ديـــ مـاهواره،

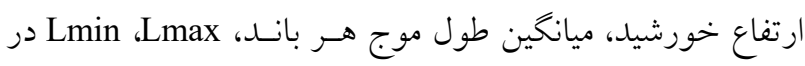
محسيط نرمافـزار IDRISI Taiga روى تصـاوير اوليـه صسورت كرفت، سبِ تصاوير در محدوده منطقه مورد مطالعه برش داده شد و در ادامه تصوير تركيب رنكى باندهاى بسץ براى تصساوير لندست TM مربوط بـه سـال 1991 (بانـد طيفى مـادون قرمـز

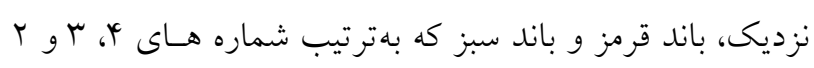
است) و تركيب باندى س ه (از باند طيفى مادون قرمز نزديـك، باند قرمز و باند سبز كه بـهترتيب شـمارههاى ه، عا و ب اسـت ) براى تصاوير لندست ^ مربوط به سال هاهب ايجاد شـد كـهـ بـا 


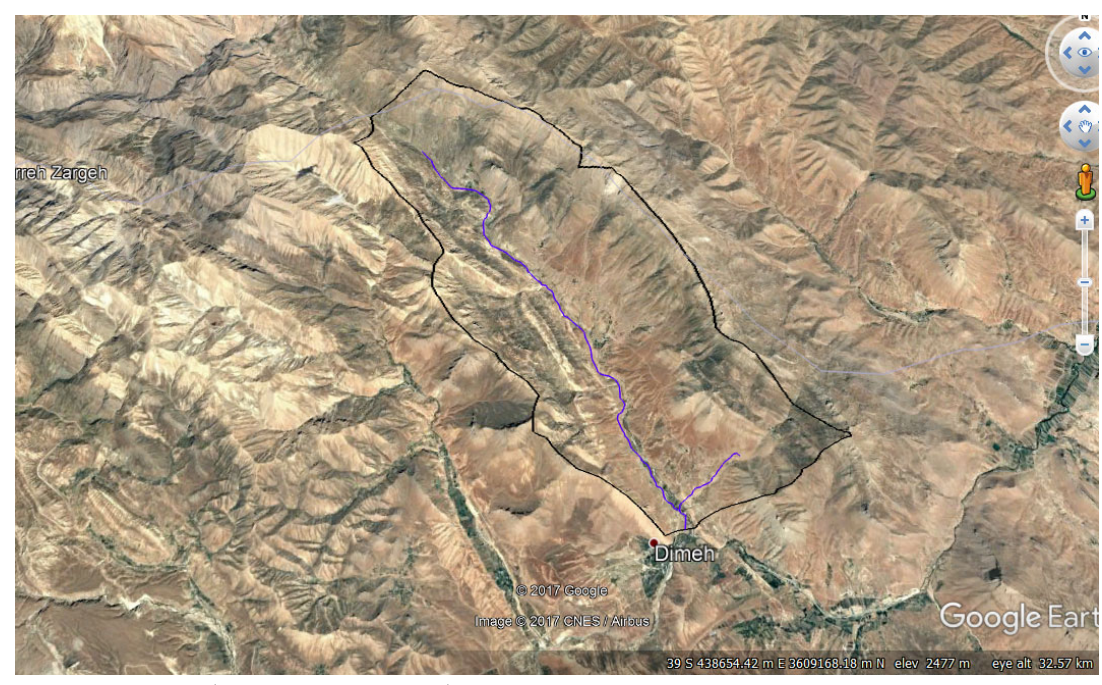

شكل r. موقعيت حوضه مورد مطالعه و آبراهههاى واقع در آن

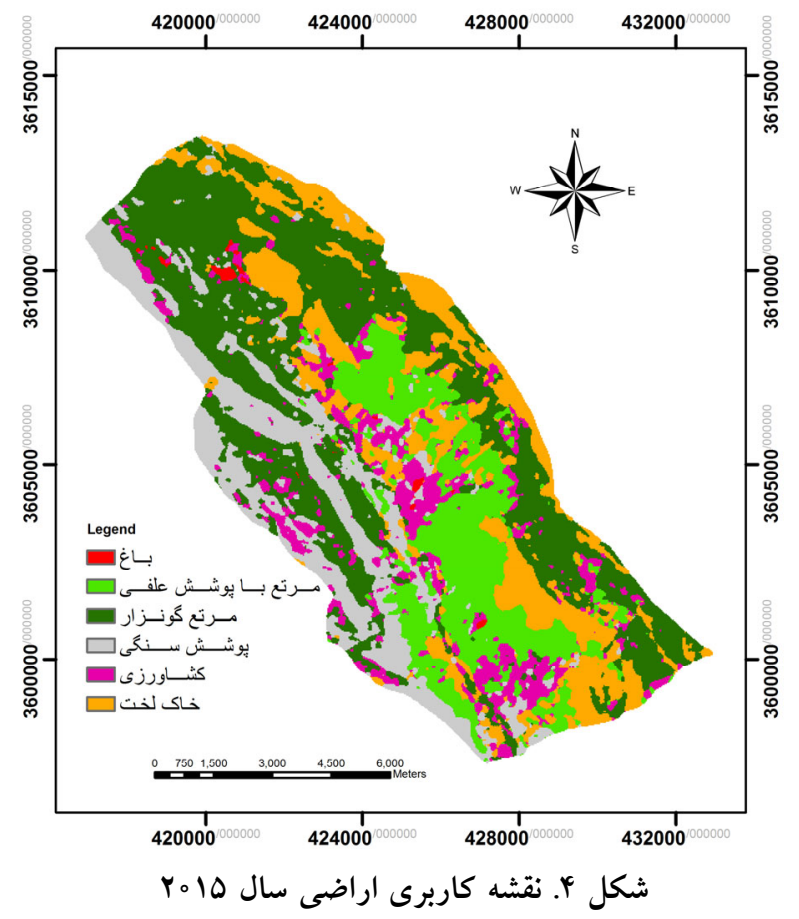

نتايج بعد از تهيه نقشههاى كـاربرى اراضسى بـهـ روش نظـارت شــده

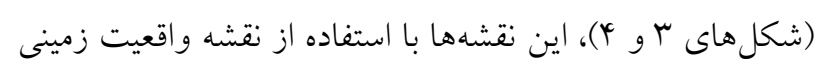
منطقه بررسى صحت شدند.

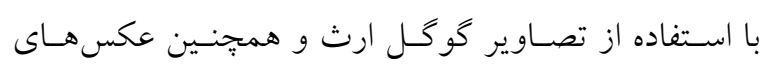

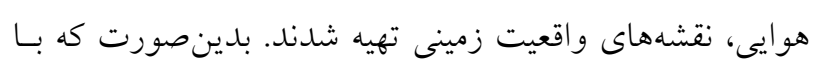

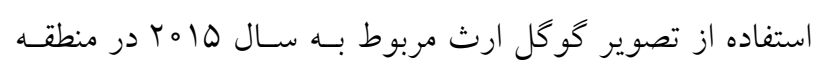

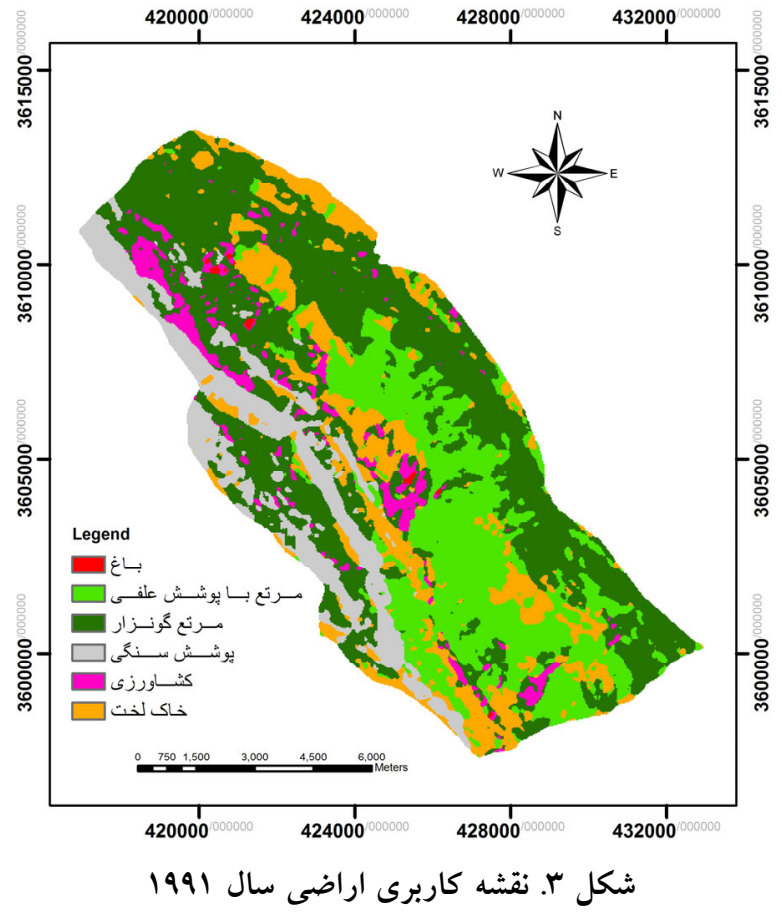

اطلاعات زمينى گو گل ارث ابتدا مرز منطقه در محسيط نرمافزار

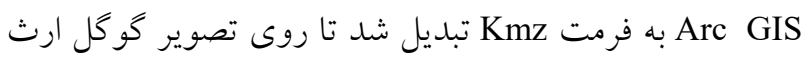

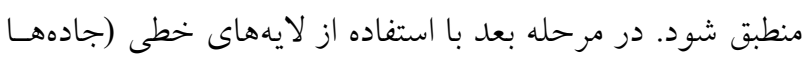

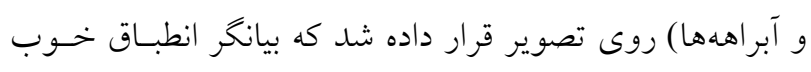

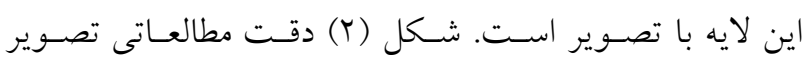

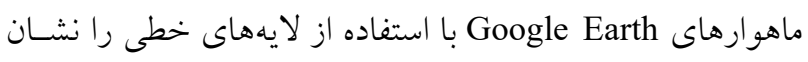
مى دهد. 
نشريه علوم آب و خاك (علوم و فنون كشاورزى و منابع طبيعى) / سال بيست و سه / ويزُهنامه سيل و فرسايش خاك / زمستان \هـا
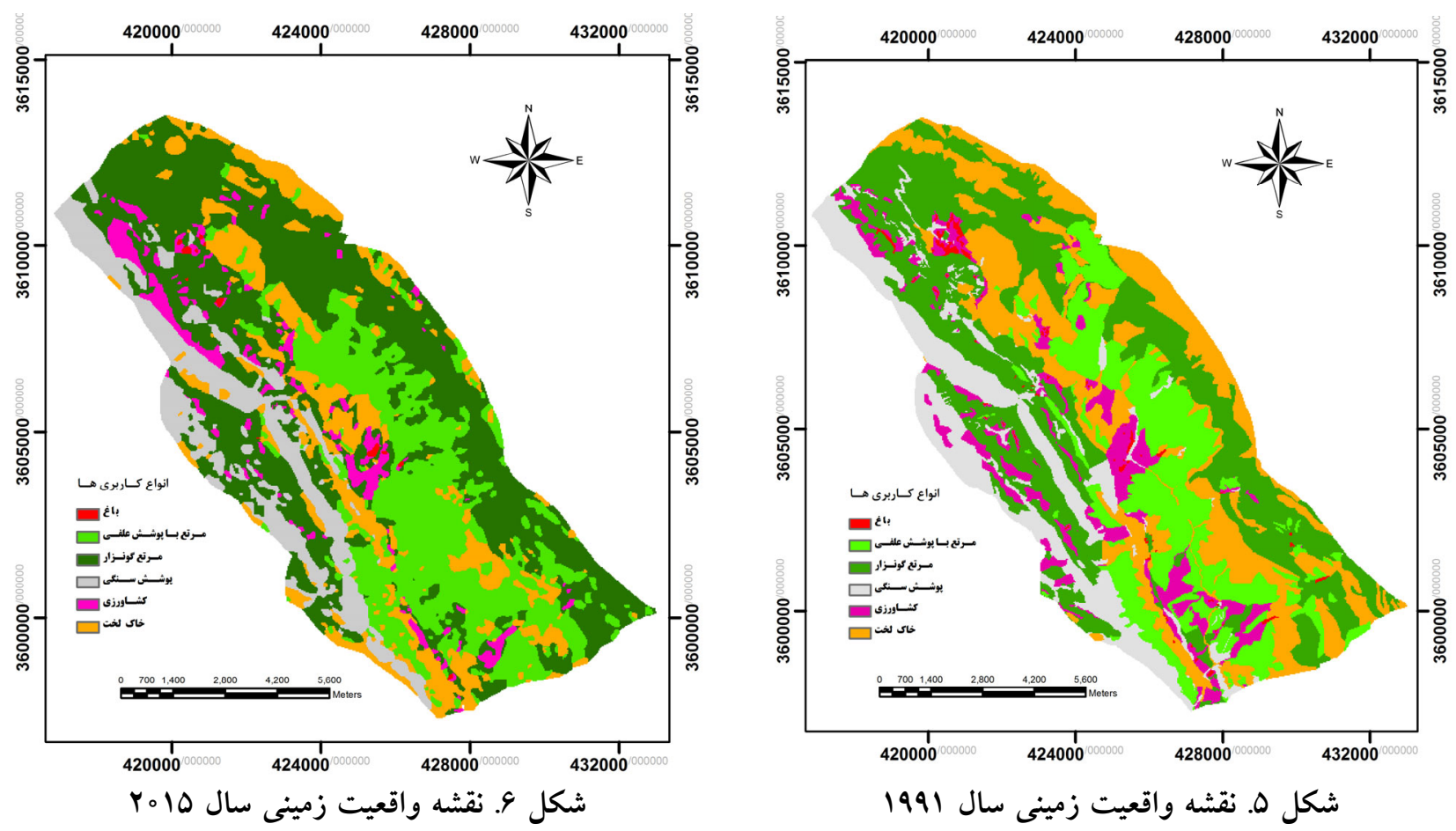

در كام بعدى، نقشـه كـاربرى اراضى سـال 1991 و نقشـهـ

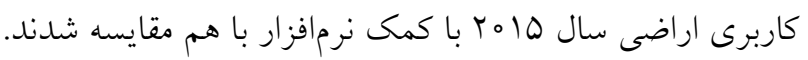

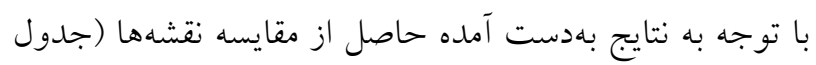

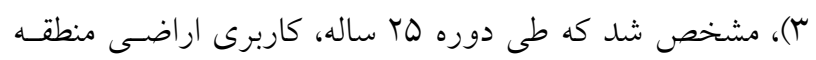

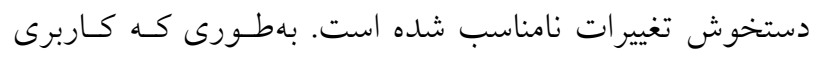

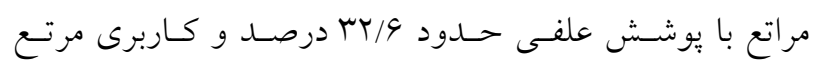

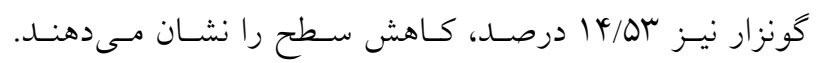

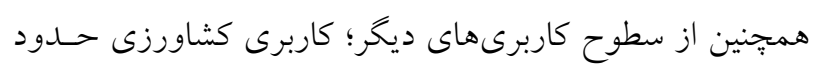

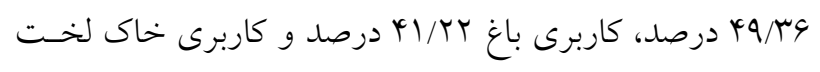

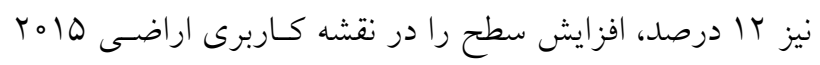
نسبت به 1991 نشان مى دهند.

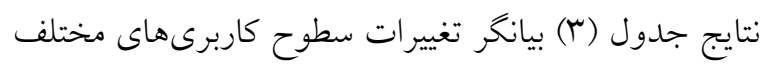

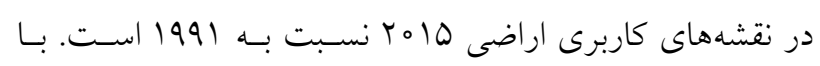

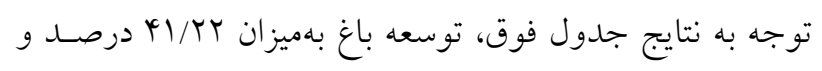

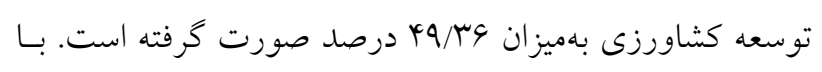
مقايسه بيكسل به بيكسل نقشهـهاى كـاربرى اراضسى و نتسيج

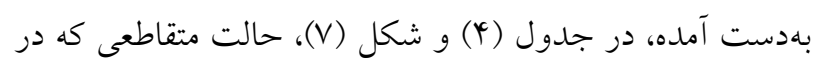

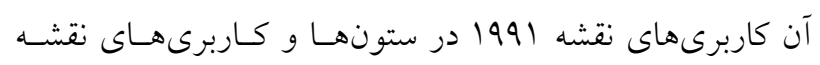
مورد مطالعه، نقشه واقعيت زمينى براى مقايسـه نقشـه كـاربرى

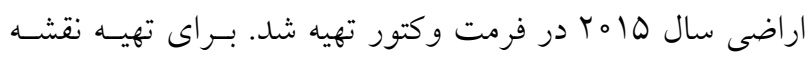

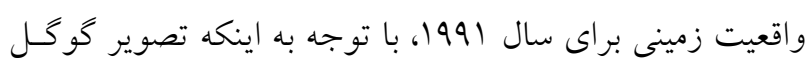

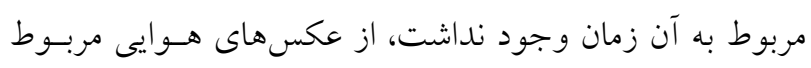

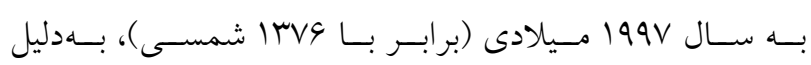

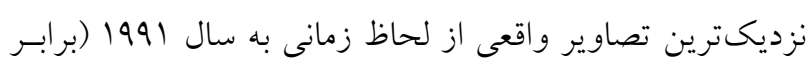

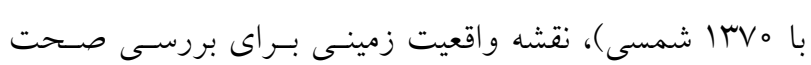

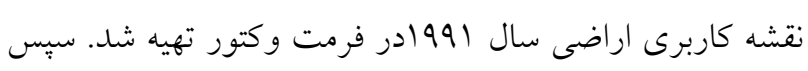

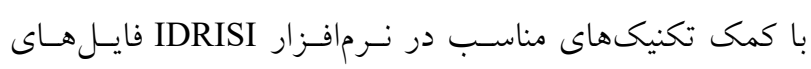

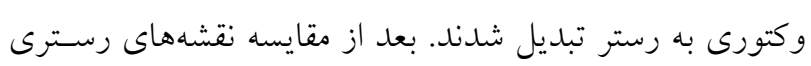

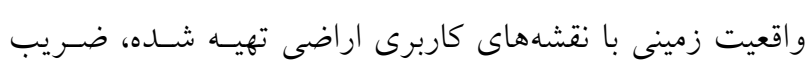

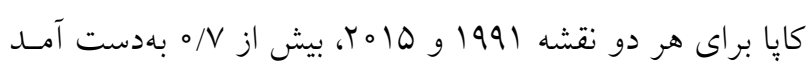
و صحت طبقهبندىها و نقشههاى كـاربرى اراضسى تهيـهـ شـده،

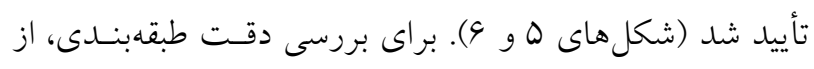

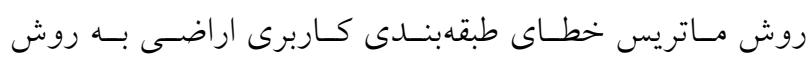

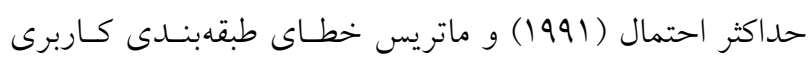

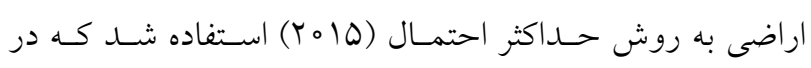

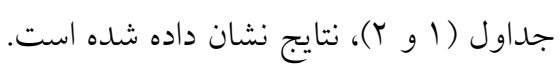


جدول 1. ماتريس خطاى طبقهبندى كاربرى اراضى به روش حداكثر احتمال (1991)

\begin{tabular}{|c|c|c|c|c|c|c|c|c|}
\hline خطاى حذف & خطاى اضافه & لخاك & كشاورزى & سوشش سنش & كونز & با يوشش عرتع علفى & باغ & نوع كاربرى \\
\hline$\%$ TY/GY & $\%$ & ir & س & 10 & $y_{0}$ & ץ & $Y \circ Y$ & باغ \\
\hline$\%$ & $\%$ \%/M & IV & 19 & 19 & m & rVo & 11 & مرتع با بوشش علفى \\
\hline$\% / 9 / 41$ & $\% 11 / 40$ & 10 & TA & 11 & MGY & rA & r & مرتع گونزار \\
\hline$\% 1 \% / 90$ & $\% 14 / 09$ & ro & 14 & $M$ & 14 & 19 & 9 & يوشش سنكى \\
\hline$\% / r / \mu Y$ & $\% \circ / \Delta \wedge$ & r & rAT & IV & rV & 10 & Tr & كشاورزى \\
\hline$\%|r / 9|$ & $\% / \mathrm{VA}$ & YAS & 0 & ro & V & 10 & 14 & خاى لخت \\
\hline- & - & $\% \triangle Q / Y Q$ & $\% / \Lambda 1 / \circ \Delta$ & $\%$ Y I/VD & $\%(\Lambda Y / Y I$ & $\%$ Vq/9r & $\% .9 \circ / \mathrm{V} \Delta$ & صحت توليد كننده \\
\hline - & - & $\% / \wedge 9 / 10$ & $\%$ VN/N & $\% \vee V Q / 1 Q$ & $\%$ VN/99 & $\%$ VA/AD & $\% / \mathrm{NV} / \mu_{1}$ & صحت كاربر \\
\hline
\end{tabular}

جدول Y. ماتريس خطاى طبقهبندى كاربرى اراضى به روش حداكثر احتمال (10)

\begin{tabular}{|c|c|c|c|c|c|c|c|c|}
\hline خطاى حذف & خطاى اضافه & لخاى & كشاورزى & سوشش سنى & كونز & با بِوشش عرتع علفى & باغ & نوع كاربرى \\
\hline$\% 1 \% / \mu_{G}$ & $\% / 1 / 99$ & ro & kr & 11 & ro & $r_{0}$ & ror & باغ \\
\hline$\% 1 \circ / \mu r$ & $\% 1 \mathrm{~V} / 94$ & IV & TY & 14 & ro & ra. & Ir & مرتعبايوشش علفى \\
\hline \% & $\% 1 \circ / 0 \mathrm{~V}$ & IV & ro & r & rar & 19 & 14 & مرتع گونزار \\
\hline$\% / \Delta / \Lambda \Lambda$ & $\%|Q / 4|$ & rV & 14 & r99 & 。 & 11 & $r$ & يوشش سنگى \\
\hline$\%$ & $\%$ \% & 11 & rqA & $\circ$ & r & 10 & YI & كشاورزى \\
\hline$\% / r Q / Y q$ & $\% 10 / 91$ & Mls & $\circ$ & 19 & Mr & $\wedge$ & $\circ$ & خاى لخت \\
\hline- & - & $\% / \wedge 9 / 01$ & HAYMY & $\% / \Lambda \circ / 4$ & $\% / \wedge \mu / \circ \Lambda$ & $\% \vee v q / \mathcal{F V}$ & $\% .9 \Lambda$ & صحت توليد كننده \\
\hline- & - & $\% \vee v / v \circ$ & $\%$ /VY/AV & \% & $\%$ \% AYTY & \%AYNG & $\%$ & صحت كاربر \\
\hline
\end{tabular}

جدول r. مقايسه سطوح كاربرىهاى مختلف در تصاوير ها 10 نسبت به 1991 (مساحت ها برحسب هكتار)

\begin{tabular}{|c|c|c|c|c|}
\hline درصد تغيرات & مقدار تغييرات & تصاوير ه|ه & تصاوير 1991 & نوع كاربرى \\
\hline$+Y I / T r$ & $r \Delta / v r$ & $\Lambda 9 / 9 \mathrm{~V}$ & $0 \circ / 94$ & باغ \\
\hline$-M Y / 90$ & $919 / 41$ & $1 \wedge \wedge 9 / \Delta 0$ & $r \Lambda \circ \Delta / q r$ & مرتع بايوشش علفى \\
\hline$-1 \% / \Delta r$ & $990 / 01$ & $r \wedge \Lambda \Delta / r)$ & $Y Q Y Q / V T$ & مرتع گونزار \\
\hline$+Y N / 19$ & $\Delta \Delta V / 19$ & $19 \vee 0 / 90$ & $|\&| \Lambda / V G$ & يوشش سنكى \\
\hline$+4 q / \mu q$ & VYYMT & IFGV/TV & $V F Y / 9 D$ & كشاورزى \\
\hline$+\mid Y / 00$ & $r \Delta Q / 90$ & TIGY/OV & $19 \circ T / 4 T$ & خاى لخت \\
\hline
\end{tabular}


نشريه علوم آب و خاك (علوم و فنون كشاورزى و منابع طبيعى) / سال بيست و سه / ويزٔهنامه سيل و فرسايش خاك / زمستان \هـ|

\begin{tabular}{|c|c|c|c|c|c|c|c|}
\hline كل & لخت & كشاورزى & بوشخى & كونزار & با يوشش علفى & باغ & نوع كاربرى اراضى \\
\hline 994 & is & KYI & 19 & YYO & or & 119 & باغ \\
\hline$r \circ 990$ & 1000 & 19. & $r_{\circ \wedge}$ & rYAr & $1990 \mathrm{r}$ & 9 & مرتع با بوشش علفى \\
\hline $4+199$ & 1999 & p4as & Irat & rryev & roor & $\mu_{0}$ & مرتع گونزار \\
\hline r1900 & YMMI & krV & IroNr & rAYV & gor & ro & يوشش سنكى \\
\hline $19 r \circ r$ & $19 \mathrm{TV}$ & TOTY & ryl & VIar & rara & INT & كثاورزى \\
\hline YYOYT & $|\wedge \mu|$ & 199 & lor & FYYq & VOVY & 19 & خاى لخت \\
\hline $\mid r V Y \circ \Lambda$ & מוז & $\Lambda T \Delta \Delta$ & lOVGY & $0 \cdot 0 \cdot \Lambda$ & mllov & 099 & كل \\
\hline
\end{tabular}

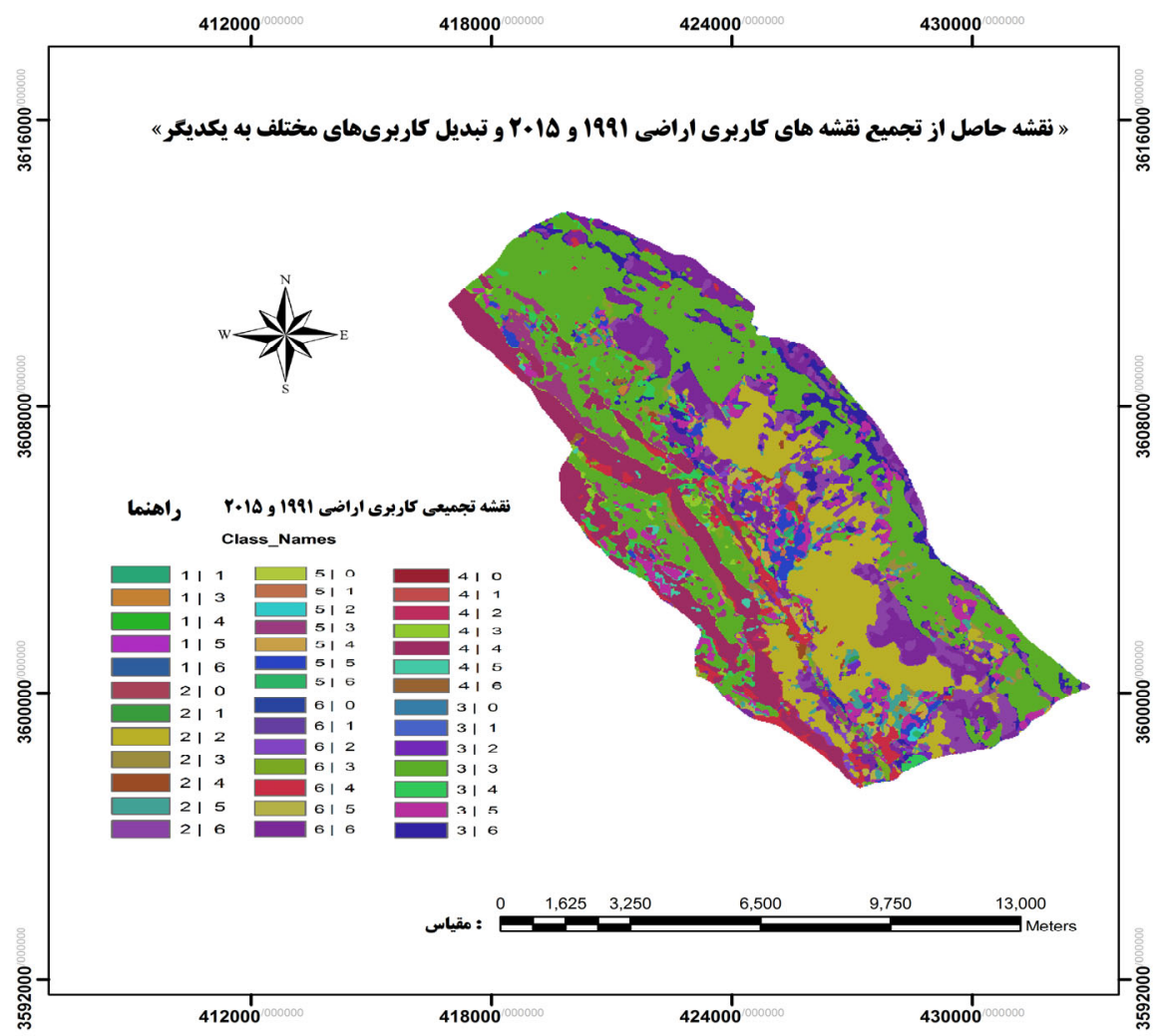

شكل V. نقشه جدول متقاطع مربوط به مقايسه بيكسلهاى كاربرىهاى اراضى 1991 و 10 rol

مـاهو ارهاى، نقشسهماى كـاربرى اراضسى طسى دو دوره زمـانى

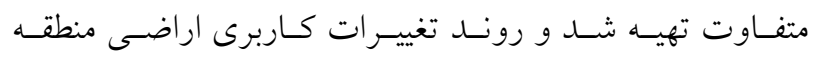

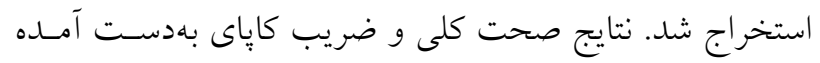
در تصاوير OLI، TM براى بررسى تغييرات در منطقه نشـان داد

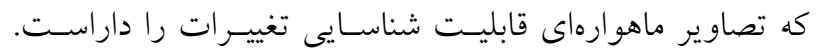

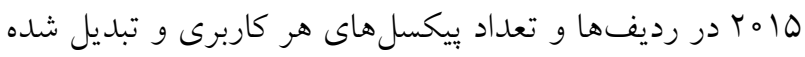
به ديخر كاربرىها، آورده شده است. بحث و نتيجه گيرى در تحقيق جارى، با استفاده از فناورى سنجش از دور و تصاوير 


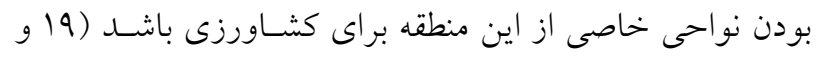

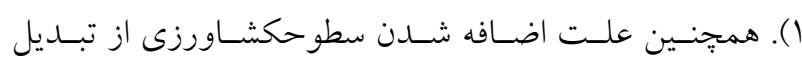
كاربرىهاى مرتعى (مرتع با يوشش علفى و مرتـع كـونزار)، بـهـ

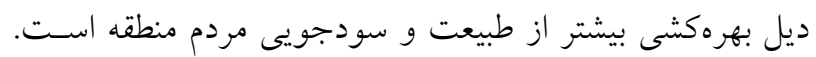

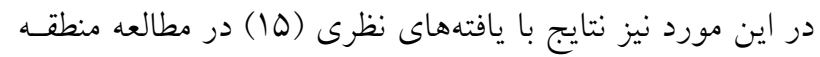

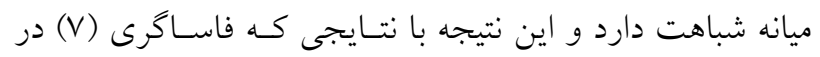

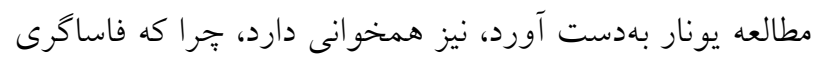
نيز نتيجه كرفت كه علت افـزايش فرسـايش در حوضسه آبخيـز يونار تبديل مراتع به اراضى كشاورزى است. اين تحقيـق نشـان

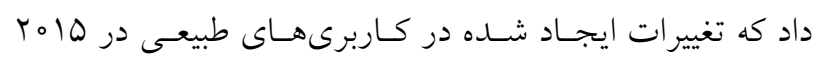

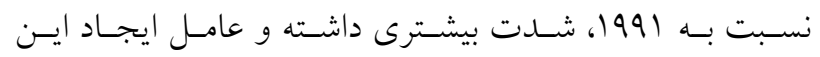
تغييرات، دخالتهاى انسانى بودهاند كه باعث تغييرات در مراتع

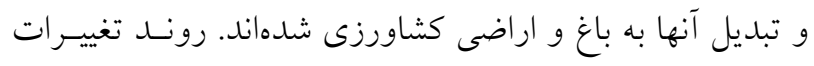

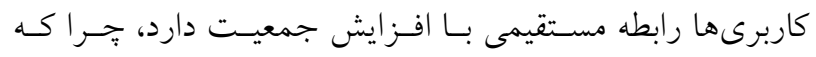

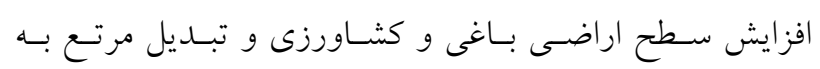

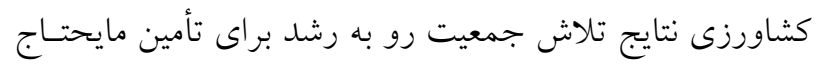

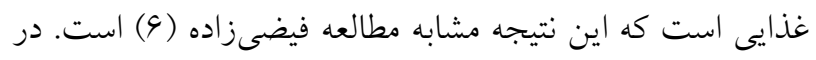

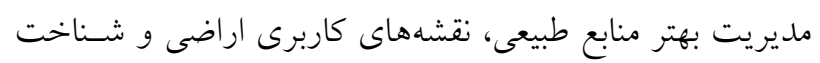

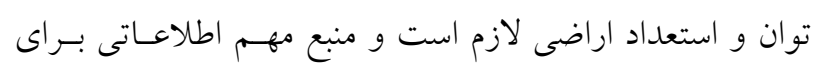

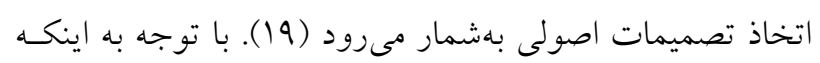

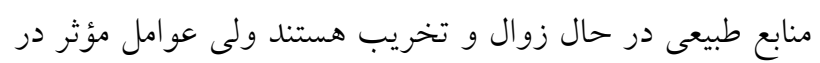

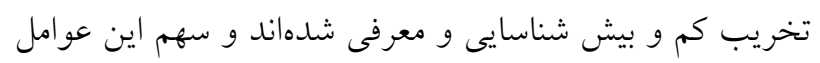

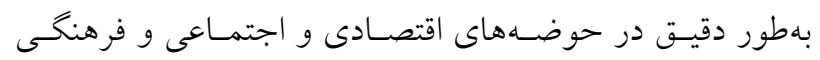
بررسى نشدهاند (Y) در صورتى كه در روند قهقر ايسى تغييـرات

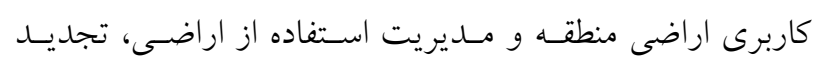

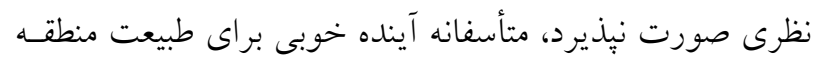

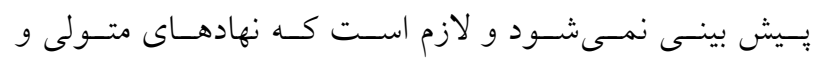

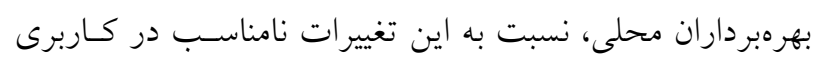

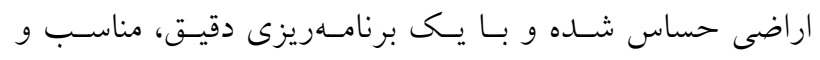

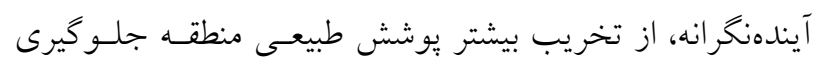

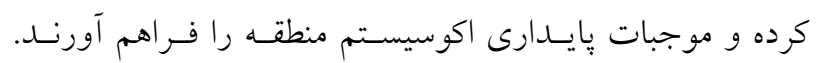

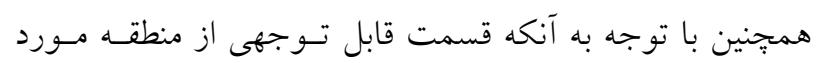

علت اين دقت بالا بـهدليل استفاده از نرمافـزار كوگـل ارث در

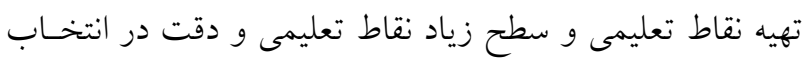
نقاط تعليمى بود و صحت قابل قبولى از طبقهبندى حاصل شد.

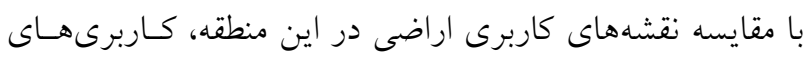

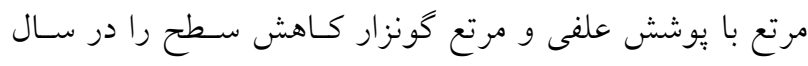

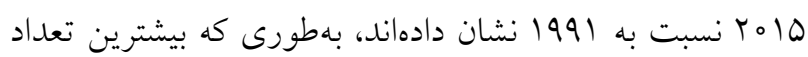

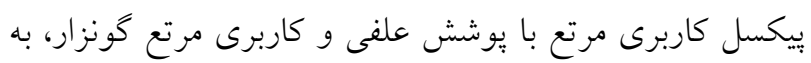

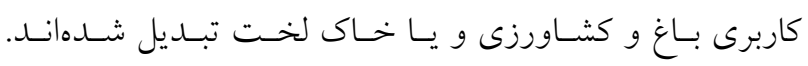

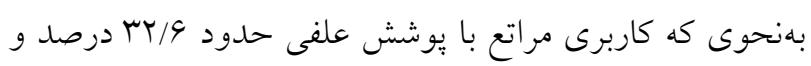

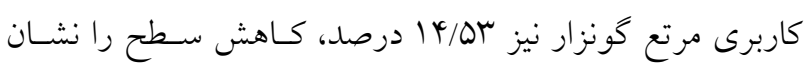
داده است. از دلايل كاهش سطح مراتع در ايسن منطقـه بـهنهاطر

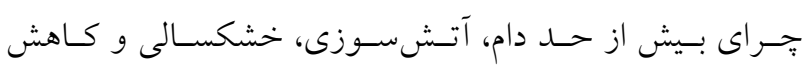

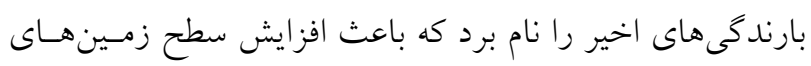

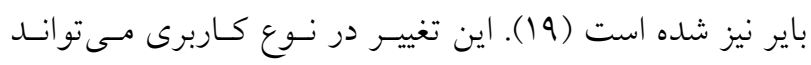

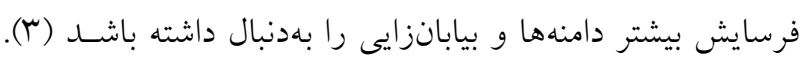

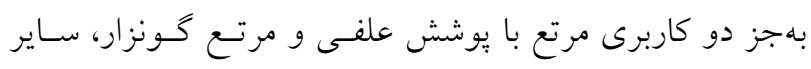

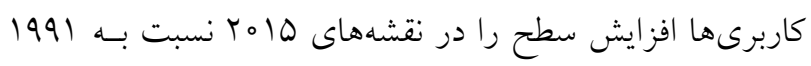

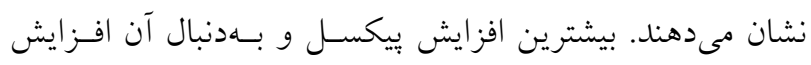

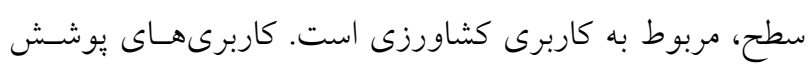

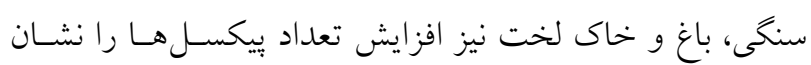

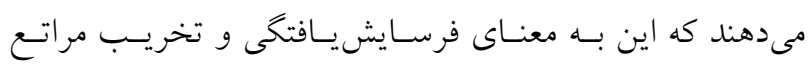

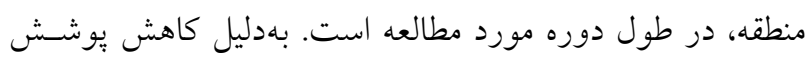

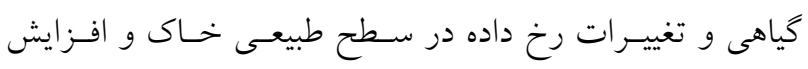

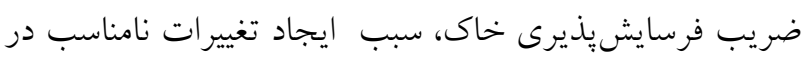

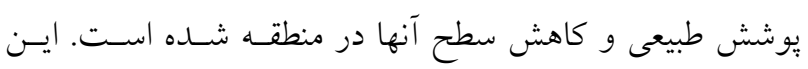

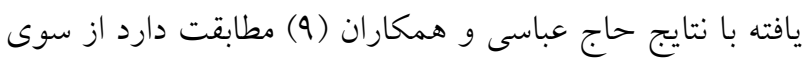

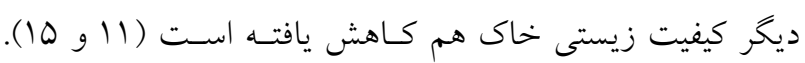

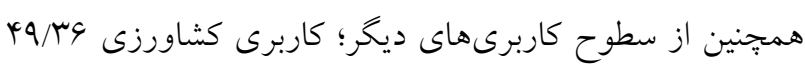

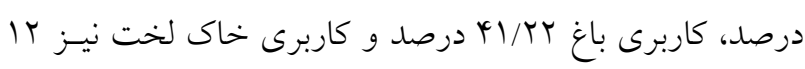

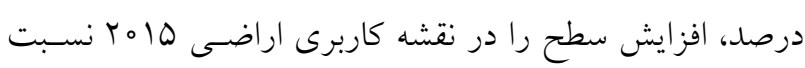

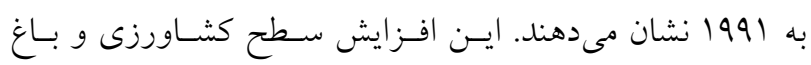

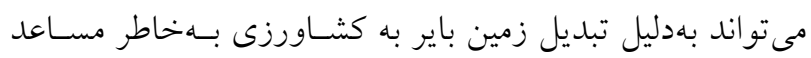




$$
\begin{aligned}
& \text { كشاورزى و همجنين شرب بيشتر است، مديريت و برنامهريزى } \\
& \text { مطالعه، زمين هاى مرتعى و كشاورزى اسـت و معيشـت بخـش }
\end{aligned}
$$

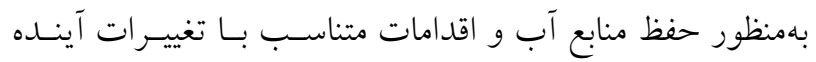

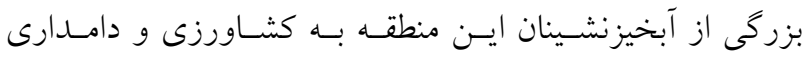

$$
\begin{aligned}
& \text { امرى ضرورى است. }
\end{aligned}
$$

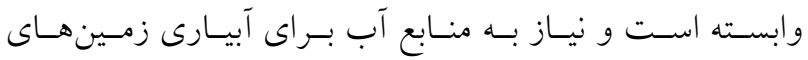

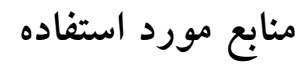

1. Abd El-Kawya, O. R., J. K. Rød, H. A. Ismail and A. S. Suliman. 2011. Land use and land cover change detection in the western Nile delta of Egypt using remote sensing data, Journal of Applied Geography 31: 483-494.

2. Ansari, N., J. SeyedAkhlaghiShal and M. H. Ghasemi. 2008. The socio-economic factors effective on the destruction of the country natural resources and its contribution in the destruction. The Research of Iran Range and Desert 15(4): 508-524. (In Farsi).

3. Bai, X., R. C. Sharma and T. R. Tateishi. 2017. A detailed and high-resolution land use and land cover change analysis over the past 16 years in the horqin sandy land, inner mongolia, mathematical problems in engineering, Journal of Mathematical Problems in Engineering 1-13

4. Barati ghahfarokhi, S., S. Soltani koopaei, S. G. Khage aldin and B. Rayegani. 1388. Investigation of land use change changes in qaleh shahrokh sub-basin using remote sensing technique (1974-2001). Journal of Agricultural and Natural Resources Science and Technology 13 (47): 349-365. (In Farsi).

5. Doran, J. W., M. Sarrantonio and M. A. Leibig. 1996. Soil health and sustainability. Journal of Agronomy 56 : 1 - 56.

6. Fayzizadeh, B. 2017. Modeling of land use change and its effects on erosion system in alavian dam basin using remote sensing techniques and GIS. Journal of Hydrogiomorphology 11: 38-21.

7. Fusagri, A. 2005. Soil erosion in the Catchment of the Unare River. Noticias Agricolas 28: 116-119.

8. Gharagozloo, A. 2015. GIS and Environmental Assessment and Planning, Second Edition, Country Surveying Organization, Tehran. (In Farsi).

9. Haj abasi M., A. Basalatpoora and A. Melali. 1997. The effect of converting rangeland to agricultural land on some physical and chemical properties of southern and southwest soils of Isfahan. Journal of Agricultural and Natural Resources Science and Technolog (In Farsi).

10. Jensen, J. R. 2007. Remote Sensing of the Environment: An Earth Resource Perspective. Taylor \& Francis Group LLC .Cartography and Geographic Information Science,Vol. 27, Issue 4.

11. Kooch, Y. and N. Moghimian. 1394. Effect of forest degradation and land use change on carbon and soil nitrogen fertility ecophysiological indices. Forest Journal of Iran. Association of Foresters of Iran 7(2): 243-256. (In Farsi).

12. Lal, R. 1997. Degradation and resilience of soils. Philosophical Transactions of the Royal Society. London (B). 325 : 997-1010.

13. Lu, D., P. Mausel, E. Brondizio and E. Moran. 2004. Change detection techniques. International Journal of Remote Sensing 25(12): 2365-2401.

14. Lundekvam, H. E., E. Romstad and L. Oygarden. 2003. Agricultural policies in Norway and effects on soil erosion. Journal of Environmental Science \& Policy 6: 57-67.

15. Nazari, N. 1392. Change of pasture land use in arable land and rainfed land and its effect on important soil characteristics in the middle zone. Quarterly Journal of Modern Agriculture Sustainable 9(2): 43-50.

16. Ramankutty, N. 2006. Global land cover change: recent progress, remaining challenges. PP: 9- 40. In: Lambin, E. F. and H. Geist. (Eds.). Land-use and Land-cover Change. Springer. Berlin Heidelberg New York.

17. Razavian, M. 2012; Urban Land Use Planning, Secretariat Publications, Tehran. (In Farsi).

18. Rawat, J. S., V. Biswas and M. Kumar. 2013. Changes in land use/cover using geospatial techniques: a case study of Ramnagar town area, district Nainital, Uttarakhand, India. Egyptian Journal of Remote Sensing and Space Science 16(1): 111-117.

19. Sabzghobayei, GH; K. Jafarzadeh, S. Dashti, Sh. Yoosefi khaneghah and M. Bazm ara baleshti. 2017. Detection of Land Use Change Using Remote Sensing and GIS. Science and Technology of the Environment 19(3): 143-157.

20. Safanian, A. and L. Khodakarami. 1390. Preparation of land use map using Fuzzy classification method. Land Design 3(4): 95-114.

21. Xiao, T. Y., B. C. Huiping Liua and G. Xiaofeng. 2015. Land cover changed object detection in remote sensing data with medium spatial resolution. International Journal of Applied Earth Observation and Geoinformation 38: $129-137$.

22. Zare, M., T. Taymoorian and M. H. Joori. 2017. Monitoring land use/cover changes using indicators of intensity of change, degree of dynamics and comparison after classification. Quarterly Journal of Ecosystems of Iran 8(1): 123136. (In Farsi). 


\title{
Investigating the Land Use Changes in the Upstream of the Zayandehrood Dam (A Study Case: The Toff-sefid Watershed, Chaharmaha and Bakhtiari Province)
}

\author{
M. Pajoohesh ${ }^{*}$, L. Cheraghpoor, A. R. Davoodian Dehkordi and A. Bozorgmehr ${ }^{1}$
}

(Received: October 14-2017 ; Accepted: July 18-2018)

\begin{abstract}
River discharge is among the influential factors on the operation of water resources systems and the design of hydraulic structures, such as dams; so the study of it is of great importance. Several effective factors on this non-linear phenomenon have caused the discharge to be assumed as being accidental. According to the basics the chaos theory, the seemingly random and chaotic systems have regular patterns that are predictable. In this research, by using methods of phase space mapping, correlation dimension, largest Liapunov exponent and Fourier spectrum power, a period covering 43 years of Zayandehrud River discharge (1971-2013) was evaluated and analyzed based on the chaos theory. According to the results, the non-integer value of the correlation dimension for Eskandari and Ghale Shahrokh stations (3.34 and 3.6) showed that there was a chaotic behavior in the upstream of Zayandehrud-Dam Reservoir. On the other hand, in the Tanzimi-Dam station, the correlation dimension curve was ascending with respect to the embedding dimension, showing that the studied time-series in the downstream of Zayandehrud-Dam Reservoir was random. The slope of the Lyapunov exponent curve for Eskandari, Ghale Shahrokh and Tanzimi-Dam stations was 0.0104, 0.017 and 0.0192 , respectively, and the prediction horizon in the chaotic stations was 96 and 59 days. The non-periodical feature of time series was studied by using the Fourier spectrum power. The wide bandwidth, besides other indices, showed that river discharge in the upstream stations of Zayandehrud Reservoir was chaotic.
\end{abstract}

Keywords: Zayandehrud Reservoir, Hydrometric station, Phase space, Correlation dimension, Fourier spectrum power, Prediction horizon

1. Department of Rangeland and Watershed Management, Faculty of Natural Resources and Earth Sciences, Shahrekord University, Shahrekord, Iran.

*: Corresponding Author, Email: drpajoohesh@gmail.com 